\title{
Part-Time Nurse Faculty Intent to Remain Employed in Academia: A Cross-Sectional Study
}

\author{
Era Mae Ferron', Ann E. Tourangeau ${ }^{2}$ \\ ${ }^{1}$ Institute for Work \& Health, Toronto, Canada \\ ${ }^{2}$ Lawrence S. Bloomberg Faculty of Nursing, University of Toronto, Toronto, Canada \\ Email: eramae.ferron@gmail.com
}

How to cite this paper: Ferron, E.M. and Tourangeau, A.E. (2017) Part-Time Nurse Faculty Intent to Remain Employed in Academia: A Cross-Sectional Study. Open Journal of Nursing, 7, 202-221. https://doi.org/10.4236/ojn.2017.72018

Received: October 29, 2016

Accepted: February 13, 2017

Published: February 16, 2017

Copyright ( 92017 by authors and Scientific Research Publishing Inc. This work is licensed under the Creative Commons Attribution International License (CC BY 4.0).

http://creativecommons.org/licenses/by/4.0/

\section{c) (7) Open Access}

\begin{abstract}
The purpose of this study was to test and refine a model of part-time nurse faculty intent to remain employed in the academic organization. Crosssectional survey methods were used. A total of 282 part-time nurse faculty working in colleges or universities in Ontario, Canada were invited to participate. Survey instruments and items measured demographic, workplace, nurse responses to the workplace, and external variables. Correlation, multiple regression, and mediation analyses were conducted using data from 119 participants (47.6\% response rate). Of the 19 variables hypothesized to affect intent to remain employed in the academic organization, seven influenced intent to remain. The resulting model indicated that the older the part-time nurse faculty member, the lower the level of intent to remain and the more years worked in the organization, the higher the level of intent to remain. The more opportunities perceived to exist outside of the employing organization, the higher the level of intent to remain. Additionally, the more satisfied part-time nurse faculty were with their job overall, the higher their level of intent to remain. In the workplace, the more support from the leader, the more formal or informal recognition received, and the more fair work procedures were perceived to be, the higher levels of part-time nurse faculty intent to remain employed in the academic organization, mediated by job satisfaction. Although age, organizational tenure, and external career opportunities are non-modifiable variables, deans and directors can encourage part-time nurse faculty to remain employed in their academic job by focusing on enhancing overall job satisfaction. Effective strategies may include formal or informal acknowledgement of good performance, consistent verbal and behavioural support, and implementation of procedural practices, such as performance evaluations and pay raises in a fair manner.
\end{abstract}

\section{Keywords}

Intent to Remain, Intent to Stay, Retention, Part-Time Nurse Faculty, 
Nurse Faculty, Nursing Faculty

\section{Introduction}

The shortage of nurses is widespread across all nursing roles, including nurse faculty. In Canada, the supply of faculty is a major factor affecting the country's ability to increase its educational and workforce capacity. Nurse faculty represent a small proportion of Canadian nurses. In 2015, only $3.7 \%$ of the workforce was employed in the academic sector [1], some of whom may not work as faculty. Despite their small numbers, nurse faculty is responsible for preparing future nurse clinicians, educators, researchers, and leaders while creating and using nursing knowledge through role modeling, research, and scholarship. The shortage of nurse faculty may contribute to a reduction of nursing programs and erosion of research needed to advance practice [2]. [3] more ominously stated that the health of the population is at stake without well-prepared faculty. Along with their full-time counterparts, part-time nurse faculty play an important role in producing the nursing workforce. In the 2013-2014 academic year, 63.5\% of nurse faculty working in Canadian nursing schools were part-time, up from approximately $46 \%$ in the 2010-2011 academic year [4] [5]. As post-secondary nursing programs increase their number of part-time nurse faculty, organizational efforts to promote retention behaviour should be a priority. However, little is known about what specific factors influence part-time nurse faculty retention.

\section{Literature Review}

\section{Theoretical Perspectives of Intent to Remain Employed}

In recent years, more research has focused on identifying the factors that influence nurse faculty intent to remain employed (ITR) in their academic positions. This work is timely given the shortages that continue to impact nursing schools and the profession's efforts to increase the workforce. As will be evident below, theories and research generated differ in complexity and in identification of predictor variables. Predictor variables are numerous, not tested consistently across studies or conceptualized differently. This makes comparisons challenging. More common among theories is the proposition of ITR being a multi-stage, attitudinal, decisional, and behavioural process [6]. This perspective draws from the seminal work of [7] [8] who developed the model, Theory of Reasoned Action, for the prediction of behavioural intentions and/or actual behaviour. The behavioural component relates to the act of retention. The decisional component describes the intention to act viewed as the direct causal variable through which other variables influence actual retention behaviour [9] [10]. The attitudinal component includes, but is not limited to, job satisfaction and organizational commitment. The main premise of the theory is that behavioural intentions are the direct and most significant determinants of behaviour. Therefore, nurses 
who intend to remain employed in the organization are likely to remain employed [9] [11] [12] [13] [14] [15]. Several nurse faculty ITR models are briefly described below.

Candela et al.'s model. In a recent cross-sectional survey study, [16] tested their hypothesized model of ITR on 808 nurse faculty working in the US. Using structural equation modeling (SEM), several direct and indirect relationships were found to be statistically significant predictors of ITR. ITR was directly affected by nurse faculty satisfaction with work, perceptions of administration's support for faculty, perceived teaching expertise, and generational membership. ITR was indirectly impacted by perceived teaching expertise and perceptions of administration's support for faculty through satisfaction with work.

Tourangeau et al.'s model. [17] conducted a cross-sectional survey to test their hypothesized model of predictors of nurse faculty 5-year ITR with 650 full-time and part-time nurse faculty working in colleges or universities in Ontario, Canada. Using stepwise regression analysis, they found that 10 of the 27 hypothesized factors predicted ITR. These predictors were organized into four categories: 1) personal characteristics-having dependents, proximity to retirement, satisfaction with work and life balance; 2) work environment and organizational support-financial support for advanced education, satisfaction with job status, satisfaction with access to required human resources, quality of the relationship with colleagues, employed full-time; 3) job content-quality of education; 4) external characteristics-being unionized. The model explained $25.4 \%$ of the variance in ITR for the next five years.

Daly and Dee's model. [18] tested their model of faculty ITR on 768 full-time instructional faculty from 15 public universities in the US. Instructional faculty was defined as members of the instructional/research staff who were employed full-time and whose major regular assignment was teaching. They proposed that ITR is directly influenced by several constructs, grouped into four categories: 1) structural variables-autonomy, communication openness, distributive justice, role conflict, and workload; 2) psychological variables-job satisfaction and organizational commitment; 3) demographic variables-gender, race, marital status, academic rank, years in current institution, and years in profession, and; 4) external environment variables-job opportunity and kinship responsibility. They also hypothesized that the structural and external environment variables indirectly predicted ITR through the psychological variables, job satisfaction and organizational commitment. Using path analysis, it was found that job satisfaction, organizational commitment, and job opportunity directly influenced faculty ITR. Autonomy, communication openness, and role conflict directly predicted both job satisfaction and organizational commitment. Distributive justice indirectly predicted ITR through organizational commitment. The model explained $53 \%$ of variance in faculty ITR.

Al-Omari et al.'s model. [19] tested their hypothesized model of faculty ITR on a sample of 139 full-time instructional faculty from various departments in a public Jordanian university. They hypothesized that several variables grouped 
into four categories directly influenced ITR: 1) work life variables-autonomy, communication openness, distributive justice, role conflict, and workload; 2) psychological variables-job satisfaction and organizational commitment; 3) external variable-job opportunity; and 4) demographic variables-gender and faculty rank. They also hypothesized that the work life, external, and demographic variables indirectly influenced ITR through job satisfaction and organizational commitment. Using SEM, they found that the model explained $47 \%$ of variance in ITR. Job opportunity, job satisfaction, and organizational commitment directly predicted ITR. Autonomy, communication openness, role conflict, and workload predicted ITR indirectly through both job satisfaction and organizational commitment. Distributive justice indirectly predicted ITR through organizational commitment only.

Based on theoretical perspectives and previous research, a model of part-time nurse faculty intent to remain employed in the academic setting was developed. Nineteen relationships were hypothesized. See Figure 1 for an illustration of the model. Plus and minus signs represent predicted positive and negative relationships, respectively. This study addressed the following research question: What are the determinants of part-time nurse faculty intent to remain employed in the academic organization?

\section{Methods}

A cross-sectional survey design was used. A faculty member was included if she/he met the following inclusion criteria: a) a registered nurse (RN); b) employed by a college or university nursing program in the Province of Ontario, Canada; c) currently employed on a part-time basis; d) has taught or will teach RN students or registered practical nursing (RPN) students within the past year or over the next year, and; e) agreed to be contacted for research inclusion purposes. Faculty were excluded if a) they were not an RN (e.g., registered practical nurse); b) they were contractually employed on a full-time basis, and; c) they were primarily employed as an administrator (e.g., dean or director). A selfreport questionnaire was mailed to the home of all eligible nurse faculty. Eligible participants were contacted up to five times over a 10-week period following methods proposed by [20].

Three full-time nurse faculty members at the academic organization where the primary investigator was affiliated agreed to participate in a pilot feasibility test. Minor changes were made to improve clarity of instructions and questionnaire format. The questionnaire consisted of 14 valid and reliable scales and specific individual questions about ITR, demographics, work rewards, and external career opportunities.

Confirmatory factor analysis was conducted to assess scale validity using SEM software AMOS version 18. Factor loadings were estimated using maximum likelihood estimation. Model fit was examined by assessing the model as a whole as indicated by the chi-square test, its p-value, and goodness-of-fit indices [21]. 


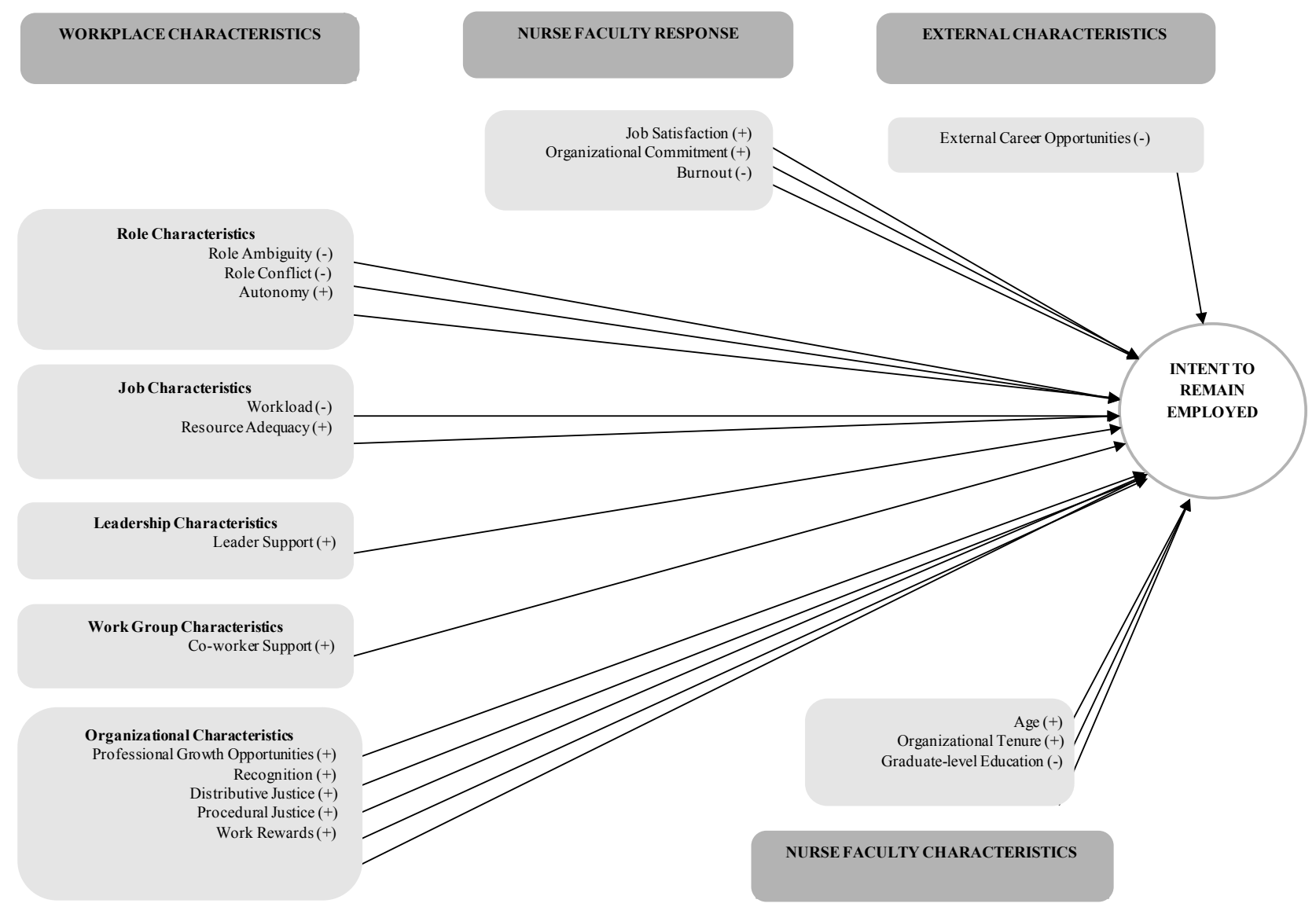

Figure 1. Hypothesized model of part-time nurse faculty intent to remain employed in the academic setting.

Correlation analysis and multiple linear regression were used to test relationships between hypothesized predictors and part-time nurse faculty ITR. Based on theory and previous findings, it was assumed that some independent variables are related to each other. Independent variables were entered simultaneously to identify how much unique variance in ITR each of the independent variables explains. In standard multiple regression, the portion of correlated variables that contributes to the variance in ITR is not assigned to any one independent variable. Therefore, independent variables that were highly correlated with ITR and other independent variables may appear unimportant. For this reason, both the full correlation and the unique contribution of each independent variable were considered in interpretation.

Ethics approval was obtained from the University of Toronto Health Sciences Research Ethics Board.

\section{Findings}

According to the College of Nurses of Ontario, the registering body for RNs, RPNs, and nurse practionners in Ontario, Canada, 282 part-time nurse faculty in Ontario fit the inclusion criteria based on those registered in 2011. Pre-notice letters were mailed to the home address of eligible part-time faculty. One prenotice letter was returned indicating an incorrect mailing address. Two ques- 
tionnaires were undeliverable. Twenty-nine responders were ineligible. A total of 125 part-time nurse faculty who met the inclusion criteria completed the questionnaire for a response rate of $50 \%$. Data from six responders were deleted from further analysis because of a high percentage of missing data. The final response rate was $47.6 \%$.

\subsection{Data Quality}

Data were coded and entered into SPSS 20 computer software. Normality, linearity, multicollinearity, and homoscedasticity assumptions were examined. Scatter plots of independent and dependent variables showed that age functioned curvilinearly. Therefore, age-squared was included as a predictor in regression analyses. Items included in inferential analysis with missing scores were not excessive [22] and ranged from $0.8 \%(\mathrm{n}=1)$ to $5.0 \%(\mathrm{n}=6)$. Missing values in demographic variables were imputed using pattern matching. For the independent variables, the missing completely at random (MCAR) assumption was examined using [23]'s MCAR test; missing data were missing completely at random $\left(\chi^{2}=1786, d f=1906, \mathrm{p}=0.98\right)$. Assessment of multicollinearity began with examining the correlations between all independent variables. Correlations ranged from $<0.001$ to 0.74 . The correlation of 0.74 between distributive justice and work rewards suggested collinearity. However, all variance inflation factor statistics of the independent variables were less than 10.0, ranging from 1.16 to 2.99 [24]. Therefore, there was no evidence that the assumption of multicollinearity was violated.

\subsection{Sample Characteristics}

All participants were female. The average age of the sample was 53.4 years (SD = 11.49). The majority of the sample had a nursing baccalaureate degree (45.4\%) as their highest level of RN education. Almost one third had a Master of Nursing degree (31.9\%) as their highest nursing education credentials. Almost $20 \%$ had a nursing diploma and two participants had a $\mathrm{PhD}$ in nursing $(<1 \%)$. Part-time nurse faculty worked as teachers (81.5\%) and professors (17.6\%). Participants had an average of 9.6 years in their current organization (range $=1.5-40.0$ ).

The majority of the sample worked 0.50 full-time equivalents (FTE) or less; $27.7 \%$ worked between 0.31 and 0.50 FTEs and $26.9 \%$ worked 0.30 FTEs or less. Almost $17 \%$ worked between 0.51 and 0.75 FTEs, and the remaining $18.5 \%$ worked 0.76 or more FTEs, 10 of which said they worked the equivalent hours of 1.0 FTE. Participants that reported working 1.0 FTE may have been referring to the number of hours that they put into their job, rather than the number of hours that they were hired to work.

The majority of participants (56.3\%) reported that they would not prefer a full-time position if available; $36 \%$ would choose a full-time position if available, and $7.7 \%$ were unsure. There was an almost even split between place of work$45.4 \%$ worked in a university setting and $47.9 \%$ work in a college setting. Eight individuals worked in both a college and university. These individuals were re- 
ferring to their employment in a collaborative nursing program, in which nursing education is jointly delivered by college and university partners with the university partner maintaining authority to issue baccalaureate nursing degrees [25]. Descriptive statistics for predictor variables are summarized in Table 1.

\subsection{Measurement Findings}

Each construct measured with an established instrument was assessed for validity and reliability. Findings are summarized in Table 2. With some exceptions, the instruments had sound psychometric properties.

When examining construct validity, the hypothesized models purported to measure the following constructs did not fit the data well: role conflict, pro-

Table 1. Descriptive statistics for predictor variables.

\begin{tabular}{|c|c|c|}
\hline Variable & Range & Mean $^{\star}(\mathrm{SD})$ or Proportion (\%) \\
\hline Intent to remain employed for 2 years & $1-100$ & $76.17(31.33)$ \\
\hline Age (in years) & $30-76$ & $53.40(11.49)$ \\
\hline Organizational Tenure (in years) & $1.5-40$ & $9.56(8.01)$ \\
\hline \multicolumn{3}{|l|}{ Graduate-level Education } \\
\hline Baccalaureate & - & 45.4 \\
\hline Diploma & - & 19.8 \\
\hline Master's & - & 31.9 \\
\hline $\mathrm{PhD}$ & - & $<1$ \\
\hline Workload & $1-100$ & $53.97(24.95)$ \\
\hline Resource Adequacy & $1-100$ & $48.25(20.60)$ \\
\hline Autonomy & $1-100$ & $72.98(22.99)$ \\
\hline Role Ambiguity & $1-100$ & $36.36(23.27)$ \\
\hline Role Conflict & $1-100$ & $46.16(23.27)$ \\
\hline Leader Support & $1-100$ & $69.46(27.17)$ \\
\hline Co-worker Support & $1-100$ & $70.28(24.33)$ \\
\hline Professional Growth Opportunities & $1-100$ & $55.50(23.55)$ \\
\hline Recognition & $1-100$ & $56.26(25.63)$ \\
\hline Distributive Justice & $1-100$ & $43.72(24.86)$ \\
\hline Procedural Justice & $1-100$ & $48.92(20.23)$ \\
\hline Work Rewards & $1-100$ & $43.77(31.03)$ \\
\hline External Career Opportunities & $1-100$ & $59.89(30.24)$ \\
\hline \multicolumn{3}{|l|}{ Burnout } \\
\hline Low $\mathrm{EE}^{* *} \leq 13$ & $1-24$ & $12.82(1.36)$ \\
\hline Average EE $=14-23$ & & \\
\hline High $\mathrm{EE} \geq 24$ & & \\
\hline Organizational Commitment & $1-100$ & $65.87(22.97)$ \\
\hline Job Satisfaction & $1-100$ & $75.49(25.73)$ \\
\hline
\end{tabular}

Note: *all variables standardized out of 100 except age, organizational tenure, graduate-level education, and burnout. ${ }^{*}$ emotional exhaustion. 
Table 2. Validity and reliability findings for predictor variables.

\begin{tabular}{|c|c|c|c|c|c|c|c|c|c|c|}
\hline \multirow[b]{2}{*}{ Predictor } & \multicolumn{9}{|c|}{ Confirmatory Factor Analysis } & \multirow{2}{*}{$\begin{array}{c}\text { Cronbach's } \\
\alpha\end{array}$} \\
\hline & Modification & Factor & $\chi^{2}(d f)$ & SRMR & GFI & CFI & TLI & RMSEA & Evaluation & \\
\hline Workload & - & $0.57-0.79$ & $0.002(1)$ & 0.001 & 1.00 & 1.00 & 1.00 & $0.12(0.00-0.00)$ & Adequate & 0.69 \\
\hline $\begin{array}{l}\text { Resource } \\
\text { Adequacy }\end{array}$ & $\begin{array}{c}\text { Item } \\
\text { removed }\end{array}$ & $0.37-0.87$ & $\begin{array}{l}4.25(2) \\
(0.12)\end{array}$ & 0.005 & 0.98 & 0.97 & 0.90 & $\begin{array}{c}0.09(0.00-0.23) \\
(0.20)\end{array}$ & $\begin{array}{l}\text { Adequate } \\
\text { fit }\end{array}$ & 0.66 \\
\hline $\begin{array}{c}\text { Role } \\
\text { Ambiguity }\end{array}$ & - & $0.44-0.82$ & $\begin{array}{c}14.81(9) \\
(0.10)\end{array}$ & 0.04 & 0.96 & 0.98 & 0.97 & $\begin{array}{c}0.07(0.00-0.14) \\
(0.25)\end{array}$ & Good fit & 0.86 \\
\hline Role Conflict & $\begin{array}{l}\text { Correlated } \\
\text { errors }\end{array}$ & $0.48-0.79$ & $\begin{array}{c}28.96(18) \\
\quad(0.05)\end{array}$ & 0.05 & 0.95 & 0.97 & 0.96 & $\begin{array}{c}0.07(0.01-0.12) \\
(0.21)\end{array}$ & Good fit & 0.86 \\
\hline Autonomy & - & $0.88-0.97$ & $\begin{array}{c}0.02(1) \\
(0.90)\end{array}$ & 0.001 & 1.00 & 1.00 & 1.00 & $\begin{array}{c}0.11(0.00-0.11) \\
(0.91)\end{array}$ & $\begin{array}{l}\text { Adequate } \\
\text { fit }\end{array}$ & 0.95 \\
\hline $\begin{array}{l}\text { Leader } \\
\text { Support }\end{array}$ & - & $0.73-0.87$ & & & & & & & & 0.85 \\
\hline $\begin{array}{l}\text { Co-worker } \\
\text { Support }\end{array}$ & - & $0.79-0.80$ & $\begin{array}{c}14.52(8) \\
(0.07)\end{array}$ & 0.03 & 0.96 & 0.98 & 0.97 & $\begin{array}{c}0.08(0.00-0.15) \\
(0.19)\end{array}$ & Good fit & 0.86 \\
\hline $\begin{array}{c}\text { Professional } \\
\text { Growth } \\
\text { Opportunities }\end{array}$ & $\begin{array}{l}\text { Correlated } \\
\text { errors }\end{array}$ & $0.45-0.94$ & $\begin{array}{c}2.81(1) \\
(0.09)\end{array}$ & 0.03 & 0.99 & 0.99 & 0.92 & $\begin{array}{c}0.12(0.00-0.31) \\
(0.14)\end{array}$ & $\begin{array}{l}\text { Adequate } \\
\text { fit }\end{array}$ & 0.77 \\
\hline Recognition & $\begin{array}{l}\text { Correlated } \\
\text { errors }\end{array}$ & $0.78-0.92$ & $\begin{array}{c}1.17(1) \\
(0.28)\end{array}$ & 0.01 & 0.99 & 1.00 & 0.99 & $\begin{array}{c}0.04(0.00-0.25) \\
(0.35)\end{array}$ & Good fit & 0.91 \\
\hline $\begin{array}{l}\text { Distributive } \\
\text { Justice }\end{array}$ & $\begin{array}{l}\text { Correlated } \\
\text { errors }\end{array}$ & $0.83-0.96$ & $\begin{array}{c}13.59(7) \\
(0.06)\end{array}$ & 0.02 & 0.97 & 0.99 & 0.98 & $\begin{array}{c}0.08(0.00-0.16) \\
(0.16)\end{array}$ & Good fit & 0.96 \\
\hline $\begin{array}{l}\text { Procedural } \\
\text { Justice }\end{array}$ & $\begin{array}{l}\text { Correlated } \\
\text { errors }\end{array}$ & $0.61-0.94$ & $\begin{array}{c}0.29(1) \\
(0.59)\end{array}$ & 0.005 & 0.99 & 1.00 & 1.00 & $\begin{array}{c}0.00(0.00-0.19) \\
(0.64)\end{array}$ & Good fit & 0.87 \\
\hline Burnout & $\begin{array}{l}\text { Correlated } \\
\text { errors }\end{array}$ & $0.62-0.93$ & $\begin{array}{l}24.41(15) \\
\quad(0.06)\end{array}$ & 0.03 & 0.95 & 0.99 & 0.98 & $\begin{array}{c}0.07(0.00-0.12) \\
(0.22)\end{array}$ & Good fit & 0.93 \\
\hline $\begin{array}{l}\text { Organizational } \\
\text { Commitment }\end{array}$ & $\begin{array}{l}\text { Correlated } \\
\text { errors }\end{array}$ & $0.39-0.90$ & $\begin{array}{c}31.92(23) \\
\quad(0.10)\end{array}$ & 0.03 & 0.95 & 0.99 & 0.98 & $\begin{array}{c}0.06(0.00-0.10) \\
(0.40)\end{array}$ & Good fit & 0.93 \\
\hline Job Satisfaction & - & $0.71-0.96$ & $0.84(1)$ & 0.014 & 0.99 & 1.00 & 1.00 & $0.00(0.00-0.24)$ & Good fit & 0.88 \\
\hline
\end{tabular}

fessional growth opportunities, recognition, distributive justice, procedural justice, burnout, and organizational commitment. Once revised by correlating errors or in one case, removing an item, the models adequately reflected the corresponding construct [26]. Measurement reliability was assessed with Cronbach's alpha. A reliability coefficient of 0.70 or higher is considered acceptable [27]. The Workload Index and the Resource Adequacy sub-scale did not meet the recommended internal consistency threshold of 0.70 with Cronbach's alphas of 0.69 and 0.66 , respectively.

\subsection{Correlation Results}

Correlation analyses were conducted to examine relationships among the de- 
pendent variable, ITR 2 years and the hypothesized independent variables. Six of the 20 independent variables were statistically significantly correlated with ITR at the 0.10 alpha level. The negative correlation between age and ITR indicated that the older the part-time nurse faculty, the lower the level of ITR $(r=-0.16, \mathrm{p}$ $=0.08)$. Positive correlations between ITR and leader support $(r=0.21, \mathrm{p}=$ $0.02)$, recognition $(r=0.23, \mathrm{p}=0.01)$, procedural justice $(r=0.17, \mathrm{p}=0.07)$, external career opportunities $(r=0.21, \mathrm{p}=0.02)$, and job satisfaction $(r=0.29, \mathrm{p}=$ 0.001 ) indicated that leader behaviours perceived to be supportive, formal and informal recognition practices, fairness in procedural activities, the availability of faculty positions outside of the employing organization, and overall satisfaction were associated with higher levels of ITR.

\subsection{Multiple Regression Results}

Standard multiple regression analysis of the 20 predictor variables produced a statistically significant regression model: $\mathrm{R}^{2}=0.30, \mathrm{~F}(20,98)=2.08, \mathrm{p}=0.01$, adjusted $R^{2}=0.16$. Five variables were found to be statistically significant predictors of ITR at the 0.10 alpha level: age, age-squared, organizational tenure, external career opportunities, and job satisfaction. Together, these variables predicted $22 \%$ of variance in ITR 2 years.

Examination of beta coefficients and $\mathrm{R}^{2}$ of several regression models suggested the presence of suppressor variables. A suppressor variable "increases the predictive validity of another variable (or set of variables) by its inclusion in a regression equation" [28]. This variable is a suppressor only for those variables whose regression weights are increased [28]. Age and organizational tenure were reciprocal suppressors in explaining ITR. Although these variables correlated positively with each other $(r=0.41, \mathrm{p}<0.001)$, they correlated with ITR in the opposite direction. When age and organizational tenure were included in regression analyses one at a time as predictors of ITR, the effect of age on ITR was weak $(\beta=-0.18, \mathrm{p}=0.08)$ but increased in magnitude and became increasingly significant when organizational tenure was added to the equation $(\beta=-0.28, \mathrm{p}=$ $0.008)$. For this regression model, variance explained increased from $11 \%$ to $16 \%$ $\left[\mathrm{R}^{2}=0.25\right.$, adjusted $\mathrm{R}^{2}=0.11, \mathrm{~F}(19,99)=1.77, \mathrm{p}=0.04$ and $\mathrm{R}^{2}=0.30$, adjusted $\mathrm{R}^{2}=0.16, \mathrm{~F}(20,98)=2.07, \mathrm{p}=0.01$, respectively]. Similarly, when age was not included in the equation predicting ITR, the regression coefficient with organizational tenure was relatively weak and nonsignificant $(\beta=0.14, \mathrm{p}=0.14)$. When age was included in the regression equation, the regression coefficient increased in magnitude and became statistically significant $(\beta=0.25, \mathrm{p}=0.02)$. The explained variance of this model increased from $10 \%$ to $16 \%\left[R^{2}=0.25\right.$, adjusted $\mathrm{R}^{2}=0.10, \mathrm{~F}(19,99)=1.70, \mathrm{p}=0.05$ ]. These analyses suggest that age and organizational tenure had a mutual reciprocal suppression effect. Multiple regression findings are summarized in Table 3.

\subsection{Mediation Analyses}

Mediation analyses were conducted to gain a better understanding of the associ- 
Table 3. Summary of standard multiple regression results.

\begin{tabular}{|c|c|c|c|c|c|}
\hline Variable & $\mathrm{b}$ & SE & $\beta$ & $t$ & $\mathrm{p}$ \\
\hline Age & -0.05 & 0.017 & -0.28 & -2.69 & 0.008 \\
\hline $\mathrm{Age}^{2}$ & -0.003 & 0.001 & -0.23 & -2.41 & 0.02 \\
\hline Organizational Tenure & 0.06 & 0.024 & 0.25 & 2.48 & 0.02 \\
\hline Graduate-level Education & -0.03 & 0.372 & -0.006 & -0.07 & 0.95 \\
\hline Workload & -0.15 & 0.256 & -0.07 & -0.60 & 0.55 \\
\hline Resource Adequacy & -0.21 & 0.293 & -0.08 & -0.71 & 0.48 \\
\hline Role Ambiguity & -0.12 & 0.198 & -0.06 & -0.60 & 0.55 \\
\hline Role Conflict & 0.25 & 0.207 & 0.16 & 1.19 & 0.24 \\
\hline Autonomy & 0.01 & 0.139 & 0.008 & 0.08 & 0.94 \\
\hline Leader Support & 0.06 & 0.289 & 0.03 & 0.20 & 0.84 \\
\hline Co-worker Support & -0.29 & 0.276 & -0.12 & -1.06 & 0.29 \\
\hline Professional Growth Opportunities & -0.13 & 0.169 & -0.09 & -0.74 & 0.46 \\
\hline Recognition & 0.37 & 0.240 & 0.20 & 1.55 & 0.12 \\
\hline Distributive Justice & -0.12 & 0.277 & -0.07 & -0.45 & 0.66 \\
\hline Procedural Justice & 0.43 & 0.291 & 0.18 & 1.46 & 0.15 \\
\hline Work Rewards & 0.03 & 0.135 & 0.03 & 0.25 & 0.80 \\
\hline External Career Opportunities & 0.17 & 0.094 & 0.16 & 1.77 & 0.08 \\
\hline Burnout & 0.26 & 0.192 & 0.18 & 1.35 & 0.18 \\
\hline Organizational Commitment & -0.10 & 0.193 & -0.06 & -0.50 & 0.62 \\
\hline Job Satisfaction & 0.64 & 0.220 & 0.41 & 2.91 & 0.005 \\
\hline
\end{tabular}

Note: $\mathrm{n}=119 . \mathrm{b}=$ unstandardized regression coefficient. $\mathrm{SE}=$ standard error. $\beta=$ standardized regression coefficient.

ations between predictors and ITR and the unique contribution of sets of predictors in the explanation of ITR. Significant correlations and nonsignificant regression coefficients suggested that job satisfaction mediated the association between leader support, recognition, and procedural justice and ITR. The statistically significant standardized regression coefficient between leader support and ITR $(\beta=0.21, \mathrm{p}=0.02)$ decreased and became nonsignificant when controlling for job satisfaction $(\beta=0.10, \mathrm{p}=0.34)$. The other conditions of mediation were also met: leader support was a significant predictor of job satisfaction $(\beta=0.45$, $\mathrm{p}<0.001)$, and job satisfaction was a significant predictor of ITR while controlling for leader support $(\beta=0.25, \mathrm{p}=0.01)$. Similarly, when controlling for job satisfaction, the significant coefficient between recognition and ITR $(\beta=0.23, \mathrm{p}$ $=0.01)$ became nonsignificant when controlling for job satisfaction $(\beta=0.12, \mathrm{p}$ $=0.23)$. The other conditions of mediation were also met: recognition was a significant predictor of job satisfaction $(\beta=0.47, \mathrm{p}<0.001)$, and job satisfaction was a significant predictor of ITR when controlling for recognition $(\beta=0.24, \mathrm{p}=$ $0.02)$. Mediation analyses show that the relationship between procedural justice and ITR was mediated by job satisfaction. Controlling for job satisfaction, the 
significant coefficient between procedural justice and ITR $(\beta=0.17, \mathrm{p}=0.08)$ became nonsignificant $(\beta=0.07, \mathrm{p}=0.48)$ suggesting a fully mediated relationship. The other conditions of mediation were met: procedural justice predicted job satisfaction $(\beta=0.37, \mathrm{p}<0.001)$ and job satisfaction predicted ITR when controlling for procedural justice $(\beta=0.27, \mathrm{p}=0.005)$. Study findings suggest the revised model illustrated in Figure 2. Age, organizational tenure, and external career opportunities directly impact ITR. Leader support, recognition, and procedural justice are the stimuli that part-time nurse faculty evaluate, influencing job satisfaction and, in turn, impacting their level of ITR in the academic organization.

\section{Discussion}

The purpose of this research was to develop, test, and refine a theoretical model of the determinants of part-time nurse faculty intent to remain employed in the academic organization. Findings are discussed in terms of four key areas of findings: the effect of age and organizational tenure; the effect of external career opportunities; the effect of job satisfaction, and; the effect of leadership.

\subsection{Effect of Age and Organizational Tenure on Intent to Remain Employed}

The older the part-time nurse faculty, the lower her/his level of ITR in the academic organization. These linear and curvilinear relationships indicate that as part-time nurse faculty get older, the level of ITR declines more sharply. This isn't surprising as the older one becomes, the closer to retirement, thus intention to remain in the job likely lessens. In the nursing profession, this is a particularly significant problem as part-time nurse faculty is on average, older than the nurse population [1].

The longer part-time nurse faculty works in the same organization, the higher their level of ITR. Study findings are similar to previous research [15] [29]. It is believed that increased years of employment results in higher levels of ITR because the longer one remains in an organization, the more investments made by nurse faculty within the organization. Part-time nurse faculty who have worked in one institution for an extended period of time have developed supportive and meaningful relationships with colleagues and supervisors and have accrued work rewards (e.g., salary increases, promotions, accolades). In addition, age and organizational tenure enhance each other's association with ITR. Examining the correlation coefficient between organizational tenure and ITR alone may lead to the conclusion that it is not a meaningful predictor of nurse faculty ITR. However, its inclusion in further analysis, along with its reciprocal suppressor, age, enhances the strength of their relationship with ITR. Further examination shows that the positive relationship between age and organizational tenure means that as part-time nurse faculty get older, the number of years employed in the organization increases. While these predictors are positively correlated, their effects on ITR are opposite. ITR increases the longer part-time nurse faculty work in the 


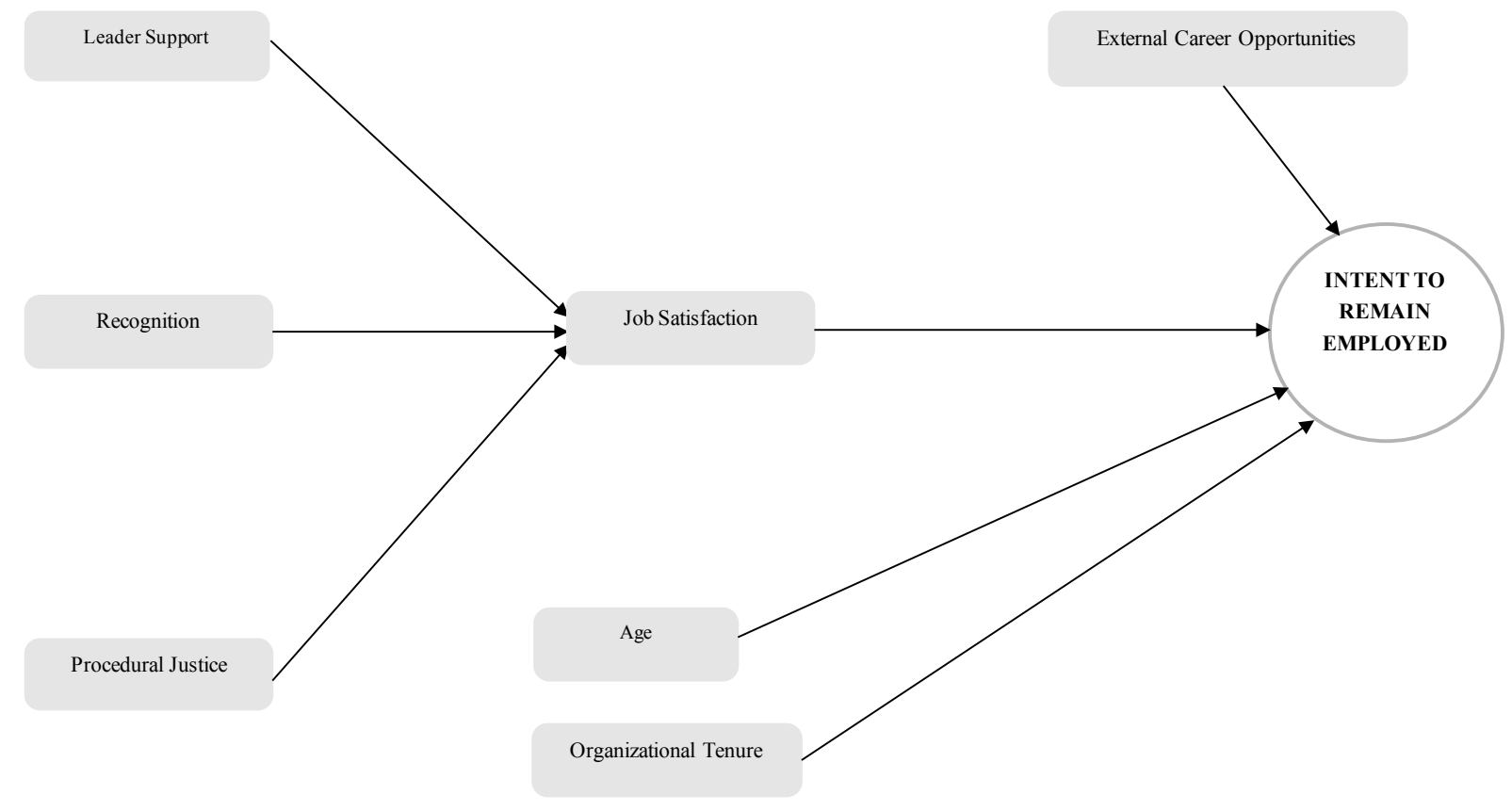

NURSE FACULTY CHARACTERISTICS

Figure 2. Revised theoretical model of part-time nurse faculty intent to remain employed in the academic setting.

same organization but decreases when age increases. This is the first known study of nurse faculty ITR to find a reciprocal suppression effect between age and organizational tenure.

\subsection{Effect of External Career Opportunities on Intent to Remain Employed}

The more perceived opportunities external to the organization, the higher the level of part-time nurse faculty ITR. This finding is in contrast to previous research. [6] [18] [30] found that nurse faculty, instructional faculty of different disciplines, and acute care nurses, respectively, had lower levels of ITR if job opportunities external to their current organization were available. The difference between this study's findings and previous work may be related to the conditions of part-time nurse faculty jobs. In areas where faculty jobs offer similar compensation packages and work environments, part-time faculty may not be willing to change jobs as the benefits of staying outweigh the costs of leaving. Comparisons between the current job and external positions may lead to the conclusion that the current position better meets personal needs and expectations which in turn increases ITR. Alternatively, part-time jobs may be unavailable. Many part-time faculty chose to work part-time, therefore, the more job opportunities, many of which are full-time, the higher the level of ITR in the 
current part-time position.

\subsection{Effect of Job Satisfaction on Intent to Remain Employed}

Study findings support a large and growing body of literature that establishes the importance of job satisfaction and its influence on ITR [16] [17] [18] [31]-[44]. In this study, job satisfaction was the strongest predictor of part-time nurse faculty ITR, similar to previous research [44] [45] [46]. The more satisfied the part-time nurse faculty is with the job, the higher the level of ITR. Job satisfaction has been found to mediate work environment characteristics, leader support, recognition, procedural justice, and ITR. This is consistent with theory and research [6] [10] [13] [18] [37] [40] [47]-[52].

\subsection{Effect of Leadership on Intent to Remain Employed}

Research into the effects of leadership behaviour on employees' intentions and behaviours to stay or leave their job is considerable [6] [15] [16] [37] [53] [54]. Consistent with the research, study results indicate that leaders who foster open, helpful, and positive relationships with their part-time nurse faculty enhance part-time faculty's ITR. This relationship was mediated by job satisfaction. Leader behaviours perceived as supportive produce higher levels of job satisfaction, which in turn, increase the level of ITR. Similarly, [16] found that nurse faculty's perceptions of administrator's support for faculty impacted faculty satisfaction with work and ITR. In several studies, it was found that supportive leader behaviours enhance job satisfaction [31] [32] [35] [37] [38] [42] [53] [55] [56] [57].

\subsection{Effect of Recognition on Intent to Remain Employed}

Acknowledging part-time nurse faculty's work-related performances or accomplishments leads to high levels of ITR. This relationship was mediated by job satisfaction. Part-time nurse faculty who are recognized for their efforts and performance are more satisfied with their job, in turn, increasing ITR. Research supports the finding of a significant relationship between recognition and ITR [15] [30] [58]. It should be noted that these studies did not examine a causal order in which higher levels of perceived recognition enhances ITR through job satisfaction, which is suggested by this study's findings. Similar to this study, [58] found positive correlations between ITR and two kinds of recognitionrecognition for outstanding performance and recognition for achievements. [15] took a different approach in measuring recognition. Their use of one item to assess satisfaction with recognition combines the two constructs. As a result, nurses evaluated the state of recognition and their satisfaction with it simultaneously. [15]'s finding may support the theory that job satisfaction is the result of one's evaluation of the work environment, supporting the causal order that recognition impacts job satisfaction, which predicts ITR. Study findings also support theoretical frameworks of nurse ITR. For instance, [59] hypothesized that praise and recognition affects clinical nurses' ITR, mediated by job satisfac- 
tion.

\subsection{Effect of Procedural Justice on Intent to Remain Employed}

Study findings suggest that when part-time nurse faculty perceives fairness is used in policy and procedural decisions, they have an increased ITR in their academic job. Similar to leader support and recognition, the relationship between procedural justices and ITR is indirect, mediated by job satisfaction. Therefore, higher levels of perceived procedural justice enhance feelings of job satisfaction, in turn, increasing the level ITR. Consistent with this study's findings, [60] found that levels of procedural justice in a sample of accounting faculty, predicted ITR. In contrast, [16] did not find that perceived equity and fairness of the promotion and tenure process predicted satisfaction with work and ITR. Differences in findings may be due to differences in the measurement of procedural justice. In general, scholars contend that employees focus on the idea of fairness expressed by the organization [60]. Fair organizational practices communicate to employees that they are valued members of the organization.

\section{Study Limitations}

The sample size of 119 part-time nurse faculty is small relative to the number of variables [61] which limits generalizability of findings. The Workload Index and the School-Level Environment Questionnaire used to measure workload and resource adequacy, respectively, had lower than desired reliability [27] perhaps preventing detection of relationships. It can be argued, however, that a relationship between these work environment factors and ITR do not exist. Correlation analysis shows that the relationship between workload and ITR, and resource adequacy and ITR are very weak and nonsignificant $(r=-0.11, \mathrm{p}=0.24$ and $r=$ $0.006, \mathrm{p}=0.94$, respectively). Furthermore, setting the level of significance to an alpha of 0.10 increases the odds of finding a true relationship in the population yet did not result in significant relationships.

Study findings suggest the presence of relationships between ITR and several variables. However, the cross-sectional approach to examining the hypothesized causal model does not confirm causality of hypothesized predictors of ITR. Further research that meets the conditions of causality are needed to strengthen claims of predictors of part-time nurse faculty ITR.

\section{Study Implications}

Deans and directors of schools of nursing are important for influencing parttime nurse faculty job satisfaction and ITR. Recognizing and acknowledging part-time nurse faculty for their achievements and performances demonstrates that the leader appreciates the employee's efforts and accomplishments thus contributing to job satisfaction. Recognition may be especially vital for part-time nurse faculty as they are not as engaged in daily organizational activities and relationships with colleagues and management because of working fewer hours. This relative detachment from their employer could lead to feelings of isolation 
and dissatisfaction without consistent and positive acknowledgement of efforts.

Part-time nurse faculty evaluate the degree of fairness displayed by their leaders in decision-making during organizational procedures which affects the employee's job satisfaction. Unlike distributive justice, procedural justice is about fairness not outcomes (e.g., pay, performance evaluations, promotions), suggesting that a fair process has a symbolic aspect not related to outcomes [60]. The use of fair procedures may convey to part-time nurse faculty that they are considered esteemed expert nurses whose background, experiences, and personality fit well in the nursing school. Establishing and implementing fair and consistent decision-making procedures may be more important to part-time nurse faculty who are not as involved in or aware of daily organizational activities. Deans and directors can cultivate procedural justice by providing fair interpersonal treatment of employees and by being transparent about organizational decisions [62].

One challenge that deans and directors may face is the reality that part-time nurse faculty have reduced number of hours at work. Less time at work reduces the face-time between a leader and the employee which can limit relationshipbuilding, opportunities for support or praise and recognition. Part-time nurse faculty is not likely as involved in departmental operations and procedures as are full-time nurse faculty. Increasing face-to-face contact with part-time faculty may not be possible. Therefore deans and directors should consider other ways to show their support, provide meaningful recognition, implement fair procedures, influence job satisfaction, and ultimately, intent to remain employed. Activities may include:

- Establish regular contact (e.g., bi-weekly) with part-time nurse faculty via email or phone apart from regular emails/phone calls about departmental operations;

- Create a monthly forum for part-time staff and the leader to meet faceto-face. The purpose may be for the leader to provide an update of the operations, praise reports, opportunities in the department (e.g., research, training, conferences, etc.), and for part-time faculty to address concerns and provide feedback. Remote online access (e.g., Skype) should be available for part-time faculty to participate;

- Develop a departmental orientation for newly-hired part-time staff. In addition to the usual information provided (e.g., benefits, resources available), include detailed information about procedures such as performance evaluation, curriculum development, and professional development opportunities.

Part-time nurse faculty also play an important role in the quality of the leaderemployee relationship. Their degree of involvement in organizational life may contribute to feelings of disconnect from daily operations, colleagues, and work culture. Therefore, it is important for part-time nurse faculty to communicate their expectations of the leader and procedures that may affect their role (e.g., performance evaluations, course assignment, and curriculum development). Recognition, whether formal or informal, serves as a compass for part- time 
nurse faculty as it provides concrete information about the degree to which her/ his efforts align with the leader's and departmental expectations. The important point is that part-time nurse faculty can initiate dialogue with their leader rather than always expecting their leader to initiate the conversation.

\section{Future Research}

Four areas of future research are suggested. First, the revised model can be tested using SEM. The causal model has the characteristics appropriate for the SEM approach (i.e., direct and indirect effects, and causal sequences amongst constructs). Second, should researchers choose to examine relationships between constructs from the original model and ITR, the workload and resource adequacy instruments should be improved. Results from confirmatory factor analysis indicate that not all aspects of particular study constructs (i.e., role conflict, professional growth opportunities, recognition, distributive justice, procedural justice, burnout, and organizational commitment) are being captured by the instruments. Improving the measurement of these constructs may increase the percentage of explained variance in ITR. Third, a longitudinal study should be conducted to test the hypothesized causal relationships found in this study to provide stronger evidence of the causal ordering of constructs [50]. Fourth, research using an interventional quasi-experimental design may provide more practical and concrete evidence for nursing administration.

\section{Conclusions}

This study provides new knowledge about the determinants of part-time nurse faculty intent to remain employed in academia. However, there is more to learn about this population of faculty. The number of variables that were found to be non-significant suggests that the ITR phenomena specific to part-time nurse faculty are complex requiring new research. The study of work motivation is one potential area. Part-time nurse faculty may be intrinsically motivated and seek enjoyment, interest, self-expression, satisfaction of curiosity, or personal challenge in their work [63]. Some work has been done in this area [64].

We have new insights into a relatively unexamined challenge that is useful for leadership in nursing college and university programs. Part-time nurse faculty are an important part of the nursing education system. It is important that qualified part-time nurse faculty are retained to help manage the current and predicted shortages of nurses. This study provides some answers about the factors that can encourage part-time nurse faculty to remain in the education system.

\section{References}

[1] College of Nurses of Ontario (2015) Membership Statistics Highlights 2014. CNO, Toronto.

http://www.cno.org/globalassets/docs/general/43069_stats/43069_membershipstatis tics-highlights.pdf

[2] Brendtro, M. and Hegge, M. (2000) Nursing Faculty: One Generation Away from 
Extinction? Journal of Professional Nursing, 16, 97-103.

https://doi.org/10.1016/S8755-7223(00)80022-8

[3] De Young, S., Bliss, J. and Tracy, J.P. (2002) The Nursing Faculty Shortage: Is There Hope? Journal of Professional Nursing, 18, 313-319.

https://doi.org/10.1053/jpnu.2002.129978

[4] Canadian Nurses Association and Canadian Association of Schools of Nursing (2015) Registered Nurses Education in Canada Statistics 2013-2014.

http://www.casn.ca/wp-content/uploads/2015/11/2013-2014-SFS-draft-report-FINA L-public-copy.pdf

[5] Canadian Nurses Association and Canadian Association of Schools of Nursing (2012) Registered Nurses Education in Canada Statistics 2010-2011. http://casn.ca/wp-content/uploads/2014/12/FINALNSFS20102011EN.pdf

[6] Tourangeau, A.E., Cummings, G., Cranley, L., Ferron, E.M. and Harvey, S. (2010) Determinants of Hospital Nurse Intention to Remain Employed: Broadening Our Understanding. Journal of Advanced Nursing, 66, 22-32. https://doi.org/10.1111/j.1365-2648.2009.05190.x

[7] Ajzen, I. and Fishbein, M. (1980) Understanding Attitudes and Predicting Social Behavior. Prentice-Hall, Englewood Cliffs.

[8] Fishbein, M. and Ajzen, I. (1975) Belief, Attitude, Intention and Behavior: An Introduction to Theory and Research. Addison-Wesley, Reading.

[9] Irvine, D.M. and Evans, M.G. (1995) Job Satisfaction and Turnover among Nurses: Integrating Research Findings across Studies. Nursing Research, 44, 246-253. https://doi.org/10.1097/00006199-199507000-00010

[10] Mueller, C.W. and Price, J.L. (1990) Economic, Psychological, and Sociological Determinants of Voluntary Turnover. Journal of Behavioral Economics, 19, 321-335. https://doi.org/10.1016/0090-5720(90)90034-5

[11] Beecroft, P.C., Dorey, F. and Wenten, M. (2008) Turnover Intention in New Graduate Nurses: A Multivariate Analysis. Journal of Advanced Nursing, 62, 41-52. https://doi.org/10.1111/j.1365-2648.2007.04570.x

[12] Iverson, H.D. (1992) Employee Intent to Stay: An Empirical Test of the Revision of the Price and Mueller Model. PhD Thesis, University of Iowa, Iowa City.

[13] Price, J.L. and Mueller, C.W. (1981) A Causal Model of Turnover for Nurses. Academy of Management Journal, 24, 543-565. https://doi.org/10.2307/255574

[14] Taunton, R.L., Boyle, D.K., Woods, C.Q., Hansen, H.D. and Bott, M.J. (1997) Manager Leadership and Retention of Hospital Staff Nurses. Western Journal of Nursing Research, 19, 205-226. https://doi.org/10.1177/019394599701900206

[15] Tourangeau, A.E. and Cranley, L.A. (2006) Nursing Intention to Remain Employed: Understanding and Strengthening Determinants. Journal of Advanced Nursing, 55, 497-509. https://doi.org/10.1111/j.1365-2648.2006.03934.x

[16] Candela, L., Gutierrez, A.P. and Keating, S. (2015) What Predicts Nurse Faculty Members' Intent to Stay in the Academic Organization? A Structural Equation Model of a National Survey of Nursing Faculty. Nurse Education Today, 35, 580589. https://doi.org/10.1016/j.nedt.2014.12.018

[17] Tourangeau, A.E., Saari, M., Patterson, E., Ferron, E.M., Thomson, H., Widger, K. and MacMillan, K. (2014) Work, Work Environments and Other Factors Influencing Nurse Faculty Intention to Remain Employed: A Cross-Sectional Study. Nurse Education Today, 34, 940-947. https://doi.org/10.1016/j.nedt.2013.10.010

[18] Daly, C.J. and Dee, J.R. (2006) Greener Pastures: Faculty Turnover Intent in Urban Public Universities. The Journal of Higher Education, 77, 776-803. 
https://doi.org/10.1353/jhe.2006.0040

[19] Al-Omari, A.A., Qablan, A.M. and Khasawneh, S.M. (2008) Faculty Members' Intentions to Stay in Jordanian Public Universities. International Journal of Applied Educational Studies, 1, 26-43.

[20] Dillman, D.A., Smyth, J.D. and Christian, L.M. (2009) Internet, Mail and Mixed-Mode Surveys: The Tailored Design Method. 3rd Edition, John Wiley \& Sons, Hoboken.

[21] Weston, R. and Gore, P.A. (2006) A Brief Guide to Structural Equation Modeling. The Counseling Psychologist, 34, 719-751.

https://doi.org/10.1177/0011000006286345

[22] Fox-Wasylyshyn, S. and El-Masri, M. (2005) Handling Missing Data on Self-Report Measures. Research in Nursing and Health, 28, 488-495. https://doi.org/10.1002/nur.20100

[23] Little, R.J.A. (1988) A Test of Missing Completely at Random for Multivariable Data with Missing Values. Journal of the American Statistical Association, 83, 1198-1202. https://doi.org/10.1080/01621459.1988.10478722

[24] Kline, R.B. (2011) Principles and Practice of Structural Equation Modeling. 3rd Edition, The Guildford Press, New York.

[25] Council of Ontario Universities (2012) Best Practices in Collaborative Nursing Agreements.

http://cou.on.ca/wp-content/uploads/2012/05/COU-Best-Practices-in-Collaborative -Nursing-Agreements.pdf

[26] Ferron, E.M. (2013) Part-Time Nurse Faculty Intent to Remain Employed in the Academic Organization. PhD Thesis, University of Toronto, Toronto.

[27] Nunnally, J.C. and Bernstein, I.H. (1994) Psychometric Theory. 3rd Edition, McGraw-Hill, New York.

[28] Conger, A.J. (1974) A Revised Definition for Suppressor Variables: A Guide to Their Identification and Interpretation. Educational and Psychological Measurement, 34, 35-46. https://doi.org/10.1177/001316447403400105

[29] Cho, S., Johanson, M. and Guchait, P. (2009) Employees Intent to Leave: A Comparison of Determinants of Intent to Leave versus Intent to Stay. International Journal of Hospitality Management, 28, 374-381. https://doi.org/10.1016/j.ijhm.2008.10.007

[30] Tourangeau, A.E., Thomson, H., Saari, M., Widger, K., Ferron, E.M. and MacMillan, K. (2012) Determinants of Nurse Faculty Intention to Remain Employed. Open Journal of Nursing, 2, 254-261. https://doi.org/10.4236/ojn.2012.23039

[31] Chen, H. and Baron, M. (2006) Nursing Directors' Leadership Style and Faculty Members' Job Satisfaction in Taiwan. Journal of Nursing Education, 45, 404-411.

[32] Chen, H., Beck, S. and Amos, L. (2005) Leadership Styles and Nursing Faculty Job Satisfaction in Taiwan. Journal of Nursing Scholarship, 37, 374-380. https://doi.org/10.1111/j.1547-5069.2005.00064.x

[33] Christian, P.L. (1986) The Impact of Expectations on Faculty Job Satisfaction. Journal of Nursing Education, 25, 378-383.

[34] Cummings, G.G., MacGregor, T., Davey, M., Lee, H., Wong, C.A., Lo, E., et al. (2010) Leadership Styles and Outcome Patterns for the Nursing Workforce and Work Environment: A Systematic Review. International Journal of Nursing Studies, 47, 363-385. https://doi.org/10.1016/j.ijnurstu.2009.08.006

[35] Donohue, J.D. (1986) Faculty Perceptions of Organizational Climate and Expressed 
Job Satisfaction in Selected Baccalaureate Schools of Nursing. Journal of Professional Nursing, 2, 373-379. https://doi.org/10.1016/S8755-7223(86)80013-8

[36] Fain, J.A. (1987) Perceived Role Conflict, Role Ambiguity, and Job Satisfaction Among Nurse Educators. The Journal of Nursing Education, 26, 233-238.

[37] Garbee, D.D. and Killacky, J. (2008) Factors Influencing Intent to Stay in Academia for Nursing Faculty in the Southern United States of America. International Journal of Nursing Education Scholarship, 5, 1-15. https://doi.org/10.2202/1548-923X.1456

[38] Gormley, D.K. (2003) Factors Affecting Job Satisfaction in Nurse Faculty: A Meta-Analysis. Journal of Nursing Education, 42, 174-178.

[39] Gurney, C.A., Mueller, C.W. and Price, J.L. (1997) Job Satisfaction and Organizational Attachment of Nurses Holding Doctoral Degrees. Nursing Research, 46, 163-171. https://doi.org/10.1097/00006199-199705000-00007

[40] Marriner, A. and Craigie, D. (1977) Job Satisfaction and Mobility of Nursing Educators: In Baccalaureate and Higher Degree Programs in the West. Nursing Research, 26, 349-360. https://doi.org/10.1097/00006199-197709000-00007

[41] Sarmiento, T., Laschinger, H. and Iwasiw, C. (2004) Nurse Educators' Workplace Empowerment, Burnout, and Job Satisfaction: Testing Kanter's Theory. Journal of Advanced Nursing, 46, 134-143. https://doi.org/10.1111/j.1365-2648.2003.02973.x

[42] Shieh, H., Mills, M.E. and Waltz, C.F. (2001) Academic Leadership Style Predictors for Nursing Faculty Job Satisfaction in Taiwan. Journal of Nursing Education, 40, 203-209.

[43] Snarr, C.E. and Krochalk, P.C. (1996) Job Satisfaction and Organizational Characteristics: Results of a Nationwide Survey of Baccalaureate Nursing Faculty in the United States. Journal of Advanced Nursing, 24, 405-412. https://doi.org/10.1046/j.1365-2648.1996.19725.x

[44] Sullivan, M.A. (2001) Relationships among Planned Mentoring Programs, Job Satisfaction, and Intent to Stay in Nurse Faculty Mentees. PhD Thesis, Alabama University, Birmingham.

[45] AbuAlRub, R.F, Omari, F.H. and Al-Zaru, I.M. (2009) Support, Satisfaction and Retention among Jordanian Nurses in Private and Public Hospitals. International Nursing Review, 56, 326-332. https://doi.org/10.1111/j.1466-7657.2009.00718.x

[46] Ruel, S.P. (2009) Factors Influencing Nursing Faculty's Job Satisfaction and Intent to Stay. PhD Thesis, University of Southern Mississippi, Hattiesburg.

[47] Ellenbecker, C.H., Porell, F.W., Samia, L., Byleckie, J.J. and Milburn, M. (2008) Predictors of Home Healthcare Nurse Retention. Journal of Nursing Scholarship, 40, 151-160. https://doi.org/10.1111/j.1547-5069.2008.00220.x

[48] Gregory, D.M., Way, C.Y., LeFort, S., Barrett, B.J. and Parfrey, P.S. (2007) Predictors of Registered Nurses' Organizational Commitment and Intent to Stay. Health Care Management Review, 32, 119-127. https://doi.org/10.1097/01.HMR.0000267788.79190.f4

[49] Mobley, W.H., Horner, S.O. and Hollingsworth, A.T. (1978) An Evaluation of Precursors of Hospital Employee Turnover. Journal of Applied Psychology, 63, 408414. https://doi.org/10.1037/0021-9010.63.4.408

[50] Price, J.L. (2001) Reflections on the Determinants of Voluntary Turnover. International Journal of Manpower, 22, 600-624. https://doi.org/10.1108/EUM0000000006233

[51] Ramsey, R.H. (2003) A National Study of Tenure-Track Business Faculty: Job Satisfaction, Continuance Commitment, and Intent to Stay. PhD Thesis, Oklahoma State University, Oklahoma City. 
[52] Reynolds, E.M.H. (1997) The Relationship between Job Satisfaction and Collegial Support to Retention of Nurse Educators in Baccalaureate and Higher Degree Nursing Programs in Virginia. PhD Thesis, Old Dominion University, Norfolk.

[53] Boyle, D.K., Bott, M.J., Hansen, H.E., Woods, C.Q. and Taunton, R.L. (1999) Managers' Leadership and Critical Care Nurses' Intent to Stay. American Journal of Critical Care, 8, 361-371.

[54] Sourdif, J. (2004) Predictors of Nurses' Intent to Stay at Work in a University Health Center. Nursing and Health Sciences, 6, 59-68. https://doi.org/10.1111/j.1442-2018.2003.00174.x

[55] Cummings, G.G., Olson, K., Hayduk, L., Bakker, D., Fitch, M., Green, E., et al. (2008) The Relationship between Nursing Leadership and Nurses' Job Satisfaction in Canadian Oncology Work Environments. Journal of Nursing Management, 16, 508-518. https://doi.org/10.1111/j.1365-2834.2008.00897.x

[56] Gui, L., Barriball, K.L. and While, A.E. (2009) Job Satisfaction of Nurse Teachers: A Literature Review. Part II: Effects and Related Factors. Nurse Education Today, 29, 477-487. https://doi.org/10.1016/j.nedt.2008.11.003

[57] Lane, K.A., Esser, J., Holte, B. and McCusker, M.A. (2010) A Study of Nurse Faculty Job Satisfaction in Community Colleges in Florida. Teaching and Learning in Nursing, 5, 16-26. https://doi.org/10.1016/j.teln.2009.05.001

[58] AbuAlRub, R.F. and Al-Zaru, I.M. (2008) Job Stress, Recognition, Job Performance and Intention to Stay at Work among Jordanian Hospital Nurses. Journal of Nursing Management, 16, 227-236. https://doi.org/10.1111/j.1365-2834.2007.00810.x

[59] Cowden, T.L. and Cummings, G.G. (2012) Nursing Theory and Concept Development: A Theoretical Model of Clinical Nurses' Intentions to Stay in Their Current Positions. Journal of Advanced Nursing, 68, 1646-1657. https://doi.org/10.1111/j.1365-2648.2011.05927.x

[60] Magner, N., Johnson, G.G. and Elfrink, J. (1994) Evidence on the Relationship between Procedural and Distributive Justice in Performance Appraisal and Accounting Faculty Attitudes and Performance. Journal of Accounting Education, 12, 325341. https://doi.org/10.1016/0748-5751(94)90025-6

[61] Tabachnick, B.G. and Fidell, L.S. (2013) Using Multivariate Statistics. 6th Edition, Pearson Education Inc., Upper Saddle River.

[62] Greenberg, J. (1990) Organizational Justice: Yesterday, Today, and Tomorrow. Journal of Management, 16, 399-432. https://doi.org/10.1177/014920639001600208

[63] Amabile, T.M. (1993) Motivating Creativity in Organizations: On Doing What You Love and Loving What You Do. California Management Review, 40, 39-58. https://doi.org/10.2307/41165921

[64] Derby-Davis, M.J. (2014) Predictors of Nursing Faculty's Job Satisfaction and Intent to Stay in Academe. Journal of Professional Nursing, 30, 19-25.

https://doi.org/10.1016/j.profnurs.2013.04.001 
Submit or recommend next manuscript to SCIRP and we will provide best service for you:

Accepting pre-submission inquiries through Email, Facebook, LinkedIn, Twitter, etc. A wide selection of journals (inclusive of 9 subjects, more than 200 journals)

Providing 24-hour high-quality service

User-friendly online submission system

Fair and swift peer-review system

Efficient typesetting and proofreading procedure

Display of the result of downloads and visits, as well as the number of cited articles Maximum dissemination of your research work

Submit your manuscript at: http://papersubmission.scirp.org/

Or contact ojn@scirp.org 